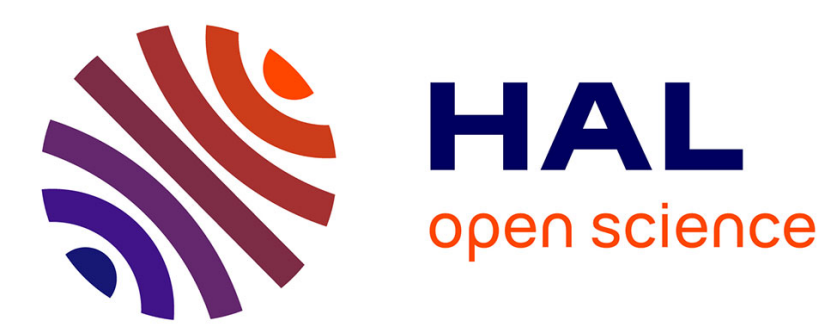

\title{
Steroid effects on intracellular degradation of insulin and crinophagy in isolated pancreatic islets
}

\author{
Monica Sandberg, L.A. Håkan Borg
}

\section{To cite this version:}

Monica Sandberg, L.A. Håkan Borg. Steroid effects on intracellular degradation of insulin and crinophagy in isolated pancreatic islets. Molecular and Cellular Endocrinology, 2007, 277 (1-2), pp.35. 10.1016/j.mce.2007.07.007 . hal-00531943

\section{HAL Id: hal-00531943 \\ https://hal.science/hal-00531943}

Submitted on 4 Nov 2010

HAL is a multi-disciplinary open access archive for the deposit and dissemination of scientific research documents, whether they are published or not. The documents may come from teaching and research institutions in France or abroad, or from public or private research centers.
L'archive ouverte pluridisciplinaire HAL, est destinée au dépôt et à la diffusion de documents scientifiques de niveau recherche, publiés ou non, émanant des établissements d'enseignement et de recherche français ou étrangers, des laboratoires publics ou privés. 


\section{Accepted Manuscript}

Title: Steroid effects on intracellular degradation of insulin and crinophagy in isolated pancreatic islets

Authors: Monica Sandberg, L.A. Håkan Borg

PII: $\quad$ S0303-7207(07)00278-X

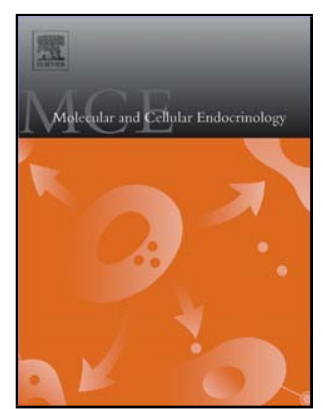

DOI: doi:10.1016/j.mce.2007.07.007

Reference: MCE 6686

To appear in: $\quad$ Molecular and Cellular Endocrinology

Received date: 28-3-2006

Revised date: $\quad 19-7-2007$

Accepted date: $\quad$ 24-7-2007

Please cite this article as: Sandberg, M., Borg, L.A.H., Steroid effects on intracellular degradation of insulin and crinophagy in isolated pancreatic islets, Molecular and Cellular Endocrinology (2007), doi:10.1016/j.mce.2007.07.007

This is a PDF file of an unedited manuscript that has been accepted for publication. As a service to our customers we are providing this early version of the manuscript. The manuscript will undergo copyediting, typesetting, and review of the resulting proof before it is published in its final form. Please note that during the production process errors may be discovered which could affect the content, and all legal disclaimers that apply to the journal pertain. 
Steroid effects on intracellular degradation of insulin and crinophagy in isolated pancreatic islets

\author{
Monica Sandberg, L.A.Håkan Borg
}

Department of Medical Cell Biology, University of Uppsala, Box 571, SE-751 23 Uppsala, Sweden 


\begin{abstract}
Under physiological conditions substantial amounts of hormone may be degraded within endocrine cells by a crinophagic process comprising fusions of secretory granules with lysosomes. Glucocorticoids may stabilise and progesterone destabilise lysosomal membranes. The effects of corticosterone and progesterone on intracellular degradation of insulin and crinophagy were determined in pancreatic $\beta$-cells, and possible pathways mediating these effects were evaluated. Pancreatic islets were isolated from mice, intracellular degradation of insulin was measured by a pulse-chase method, and crinophagy was studied by electron microscopy. The islets were exposed to $3.3,5.5$ or $28 \mathrm{mM}$ glucose with or without corticosterone, progesterone or the receptor ligands A-224817.0 and WAY-161358. Mifepristone was used to block steroid receptors and indomethacin to inhibit prostaglandin synthesis. Corticosterone caused a concentration-dependent decrease of insulin degradation at the lower glucose concentrations. Progesterone effected a concentration-dependent stimulation of insulin degradation. These results were paralleled with changes of the crinophagic activity in the $\beta$-cells. Corticosterone decreased and progesterone increased islet production of prostaglandin $\mathrm{E}_{2}$. Mifepristone abolished the steroid actions on insulin degradation and prostaglandin production. The effects of corticosterone were mimicked by the selective glucocorticoid receptor modulator A-224817.0, but in contrast to progesterone, the selective progesterone receptor agonist WAY-161358 had no effect on insulin degradation or prostaglandin production. Inhibition of cyclooxygenase blocked insulin degradation. The findings indicate that both corticosterone and progesterone could affect intracellular insulin degradation and crinophagy solely via the glucocorticoid receptor, and that prostaglandins may have a regulatory role in intracellular turnover of secretory material in pancreatic islet $\beta$ cells.
\end{abstract}

Keywords: Pancreatic islets; Corticosterone; Progesterone; Lysosomes; Intracellular insulin degradation; Prostaglandin $\mathrm{E}_{2}$ 


\section{Introduction}

Endocrine cells that produce polypeptide hormones maintain a rich supply of secretory granules, which enables an instant response to a stimulus. Hormone that is not released may be subjected to intracellular degradation. Indeed, ultrastructural observations on prolactinproducing cells (Smith and Farquhar, 1966) have indicated that secretory granules can be incorporated into lysosomes and degraded by a process denominated crinophagy (de Duve, 1969). At varying functional demands a relative overproduction of secretory material could be controlled by crinophagy. This notion is supported by observations of glucose-dependent alterations of the lysosomes in the insulin producing pancreatic $\beta$-cells (Schnell and Borg, 1985; Schnell et al., 1988; Schnell Landström et al., 1991).

However, little is known about the mechanism of the crinophagic process and its correlation to intracellular degradation of polypeptide hormones. Early experiments with isolated lysosomes have shown that glucocorticoids may stabilise lysosomal membranes (Weissmann, 1965; Miller and Smith, Jr., 1966; Symons et al., 1969), whereas other steroids, such as progesterone, may make lysosomal membranes unstable (Weissmann, 1965). Provided that crinophagy results in degradation of secretory material, a glucocorticoid and progesterone would consequently have opposite actions on both crinophagy and intracellular hormone degradation.

This hypothesis was tested by studies of the effects of corticosterone and progesterone on the $\beta$-cell lysosomes and on the intracellular degradation of insulin in isolated pancreatic islets. Alternative pathways for the action of the steroids were evaluated by experiments utilising mifepristone, which is an antagonist for both the glucocorticoid and the progesterone receptor (Baulieu, 1991; Agarwal, 1996; Cadepond et al., 1997), A-224817.0 that is a selective nonsteroidal glucocorticoid receptor modulator maintaining high transrepressive activity whilst having low transactivation effect (Elmore et al., 2001) and WAY-161358, which is a nonsteroidal progesterone receptor agonist virtually lacking any cross-reactivity with the glucocorticoid receptor (Zhang et al., 2003). Furthermore, the effects of the steroids on prostaglandin production in the islets were determined, and a possible role for prostaglandins as mediators of intracellular hormone degradation was assessed by experiments with indomethacin, which is an inhibitor of prostaglandin synthesis (Ferreira et al., 1971; Vane, 1971). 


\section{Materials and methods}

\subsection{Islet isolation and intracellular degradation of insulin}

Pancreatic islets were isolated from adult male NMRI mice (Scanbur BK, Sollentuna, Sweden) by a collagenase digestion procedure (Schnell et al., 1988).

Intracellular degradation of insulin was determined by a pulse-chase method. The islets were incubated under tissue culture conditions in TCM 199 with Hanks' salts supplemented with $100 \mathrm{ml} / 1$ heat-inactivated $\left(56^{\circ} \mathrm{C}, 30 \mathrm{~min}\right.$ ) fetal bovine serum (Sigma-Aldrich Corp., St. Louis, MO, USA), $170 \mu \mathrm{M}$ sodium benzylpenicillinate and $170 \mu \mathrm{M}$ streptomycin. To label islet proteins during a 72-h pulse period, groups of about 150 islets were maintained in medium containing 5.5 mM glucose and 1.5 GBq/1 L-[4,5- $\left.{ }^{3} \mathrm{H}\right]$ leucine (GE Healthcare Life Sciences, Chalfont St. Giles, Buckinghamshire, UK) giving a specific radioactivity of 3.3 $\mathrm{GBq} / \mathrm{mmol}$. The radioactive labelling of immunoprecipitable insulin in the islets increased during the first two days of incubation and then reached a steady state.

After the incorporation of radioactive leucine, the islets were rinsed two times in nonradioactive medium and two batches of 15 islets were homogenised by sonication $(22 \mathrm{kHz}, 50$ W) for $10 \mathrm{~s}$ in $200 \mu \mathrm{l}$ of a $50 \mathrm{mM}$ glycine buffer, $\mathrm{pH} 8.8$, containing $2.5 \mathrm{~g} / \mathrm{l}$ bovine serum albumin (BSA), and frozen. The remaining islets were divided into three aliquots and subjected to a chase-incubation for $24 \mathrm{~h}$ without radioactivity at 3.3, 5.5 or $28 \mathrm{mM}$ glucose. Corticosterone, progesterone, mifepristone and indomethacin, which all were obtained from Sigma-Aldrich Corp., St. Louis, MO, USA, A-224817.0 (2,5-dihydro-10-methoxy-2,2,4trimethyl-5-(2-propenyl)-1H-[1]benzopyrano[3,4-f]quinoline) from Abbott Laboratories, Abbott Park, IL, USA, and WAY-161358 (4-(1,4-dihydro-4,4-dimethyl-2-thioxo-2H-3,1benzoxazin-6-yl)-2-thiophenecarbonitrile) from Wyeth Pharmaceuticals, Collegeville, PA, USA, were supplied to the incubations by addition of 5 or $10 \mu 1$ from stock solutions of the substances dissolved in ethanol. It was established that the addition of $10 \mu$ l ethanol to the islet incubations neither affected immunoreactive insulin in islet homogenates nor in incubation media. After the chase period, duplicate groups of 15 islets from each glucose concentration were homogenised by sonication in $200 \mu$ l glycine-BSA-buffer, and 100- $\mu 1$ portions of the incubation media were also retrieved. The islet homogenates and incubation media were kept frozen until immunoprecipitation.

Portions of $10 \mu \mathrm{l}$ from the islet homogenates and the $100-\mu 1$ medium samples were mixed with $100 \mu \mathrm{l}$ of a $50 \mathrm{mM}$ glycine buffer, $\mathrm{pH} 8.8$, supplemented with $2.5 \mathrm{~g} / 1 \mathrm{BSA}$ and 1 $\mathrm{ml} / 1$ Triton ${ }^{\circledR} \mathrm{X}-100$, and in duplicates supplied with $10 \mu \mathrm{l}$ of guinea pig anti-human insulin 
serum (Chemicon International, Temecula, CA, USA) or $10 \mu \mathrm{l}$ normal guinea pig serum (Harlan Sera-Lab, Loughborough, Leicestershire, UK). The immune binding was allowed to proceed for $1 \mathrm{~h}$ at room temperature. Subsequently $50 \mu 1$ rProtein-A-Sepharose ${ }^{\mathrm{TM}}$ Fast Flow suspended in glycine-BSA-Triton ${ }^{\circledR} \mathrm{X}-100$ buffer to a concentration of $110 \mathrm{ml} / \mathrm{l}$ was added, and the material was tumbled for $15 \mathrm{~min}$ at room temperature and then centrifuged for $3 \mathrm{~min}$ at $4000 \mathrm{x}$ g. The Sepharose ${ }^{\mathrm{TM}}$ sediment with the anti-insulin-insulin complex was washed twice with $500 \mu 1$ glycine-BSA-Triton ${ }^{\circledR} \mathrm{X}-100$ buffer and finally resuspended in $500 \mu 11 \mathrm{M}$ acetic acid with $2.5 \mathrm{~g} / 1 \mathrm{BSA}$. After addition of $2.5 \mathrm{ml}$ Ultima Gold ${ }^{\mathrm{TM}}$ scintillation fluid, the radioactivity was determined by a liquid-scintillation spectrometer (Wallac System1400 ${ }^{\mathrm{TM}}$ ) using external standardisation. Nonspecific binding was corrected for by subtracting the radioactivity bound by normal guinea pig serum from that precipitated by immune serum.

To check if any extracellular degradation of insulin occurred in the media during the chase period two control experiments were performed. Firstly, incubation media were supplied with 5 - $10 \mathrm{ng} / \mathrm{ml}$ of crystalline mouse insulin (Novo Research Institute, Bagsvaerd, Denmark) and the recovery was measured by radioimmunoassay (Heding, 1972). Secondly, immunoprecipitable porcine $\left[{ }^{125} \mathrm{I}\right]$ iodoinsulin (PerkinElmer Life and Analytical Sciences, Wellesley, MA, USA) was determined in cultures containing 40 islets/dish as described above. No significant extracellular insulin degradation was detected by any method for up to three days irrespective of the glucose concentration or additions of corticosterone or progesterone.

\subsection{Electron microscopy and enzyme cytochemistry}

Islets from the chase incubations were prepared for electron microscopy and visualisation of acid phosphatase activity as described in detail elsewhere (Schnell and Borg, 1985, and ultrastructural studies were performed by a H-7100 transmission electron microscope from Hitachi, Tokyo, Japan.

\subsection{Measurement of prostaglandin $E_{2}$}

The content of prostaglandin $\mathrm{E}_{2}\left(\mathrm{PGE}_{2}\right)$ in the islet incubation media was measured by a competitive ELISA (GE Healthcare Life Sciences, Uppsala, Sweden). 


\subsection{Statistical analysis}

All statistics was based on independent observations. Intracellular degradation of insulin at the various experimental conditions was evaluated by $t$-statistics. Differences between the experimental groups were assessed by factorial analysis of variance in combination with Fisher's protected least significant difference test.

\section{Results}

\subsection{Glucose affects intracellular degradation of insulin}

Intracellular degradation of insulin in the pancreatic islets was determined by a pulsechase method. After the chase period, the content of radioactively labelled insulin in the islets and incubation media was measured and calculated as a percentage of the radioactive insulin in the islets retrieved immediately after the pulse incubation. Lacking insulin was regarded as degraded intracellularly, since no insulin degradation occurred in the incubation media under the present conditions.

The glucose concentration of the incubation medium influenced the fate of the labelled immunoprecipitable insulin during the chase period (Table 1). At 3.3 and $5.5 \mathrm{mM}$ glucose the insulin secretion was low, and a lot of insulin remained in the islet $\beta$-cells. Under these circumstances more than a third of the insulin was subjected to intracellular degradation $(p<$ 0.001 ). When the islets were exposed to $28 \mathrm{mM}$ glucose, the insulin secretion was greatly enhanced and the islet insulin content decreased. However, the total insulin content of the chase incubations was markedly increased. Hence, at a glucose concentration of $28 \mathrm{mM}$ there was no intracellular degradation of insulin $(p>0.05)$.

\subsection{Corticosterone decreases and progesterone increases intracellular degradation of insulin}

The addition of corticosterone or progesterone to the chase medium changed the islet handling of the labelled insulin (Fig. 1). Corticosterone caused a concentration-dependent decrease of the islet intracellular degradation of insulin. Quite the opposite was observed, when the medium was supplemented with progesterone. This resulted in a concentrationdependent stimulation of the intracellular degradation of insulin. Even at $28 \mathrm{mM}$ glucose, the additions of progesterone resulted in an intracellular degradation of about a third to one-half of the labelled insulin. 


\subsection{The effects of glucose and steroids on intracellular degradation of insulin are paralleled with structural changes of the $\beta$-cell lysosomes}

When the pancreatic islets were incubated with 3.3 or $5.5 \mathrm{mM}$ glucose, their $\beta$-cells showed a conspicuous supply of secretory granules, whereas they displayed a low content of granules at $28 \mathrm{mM}$ glucose. There was a great variation in the ultrastructure of the lysosomes of the islet $\beta$-cells. At a glucose concentration of 3.3 and $5.5 \mathrm{mM}$ most lysosomes had a heterogeneous content with various kinds of inclusions (Fig. 2A). Many of these lysosomes appeared as multigranular bodies enclosing material resembling secretory granules (Fig. 2B). These lysosomes indicated an active crinophagic process. The lysosomes predominating in the $\beta$-cells of the islets incubated with $28 \mathrm{mM}$ glucose exhibited a homogenous, very fine, particulate content of high density and a narrow light rim, or halo, just beneath their surrounding membrane (Fig. 2C). These lysosomes were defined as dense bodies and showed no signs of involvement in crinophagy.

The addition of corticosterone to the incubation medium resulted in an increased content of secretory granules in the islet $\beta$-cells. Most $\beta$-cell lysosomes in the islets treated with corticosterone appeared as dense bodies also at the lower glucose concentrations (Fig.3A). The dense bodies were entirely filled with cytochemically reactive acid phosphatase (Fig.3A, inset). Progesterone caused an apparent decrease in the number of secretory granules in the $\beta$ cells of the pancreatic islets. Numerous large multigranular bodies could be seen in the $\beta$-cells exposed to progesterone at all three glucose concentrations. Notably, there was a considerable number of $\beta$-cell multigranular bodies in the islets treated with progesterone at $28 \mathrm{mM}$ glucose (Fig. 3B). These lysosomes demonstrated always a patchy distribution of acid phosphatase activity (Fig. 3B, inset). The observations implied that corticosterone and progesterone exerted divergent effects on the lysosomal population of the islet $\beta$-cells. Corticosterone obviously decreased, whereas progesterone increased, the crinophagic activity of these cells.

\subsection{Mifepristone abolishes the effects of steroids on intracellular degradation of insulin}

The effects of corticosterone and progesterone on the intracellular degradation of insulin were moreover evaluated by experiments with mifepristone (Fig. 4). In incubations with 3.3 or $5.5 \mathrm{mM}$ glucose, $20 \mu \mathrm{M}$ mifepristone had in itself no effect on islet intracellular insulin degradation. However, when mifepristone was added to incubations containing $20 \mu \mathrm{M}$ 
corticosterone or $20 \mu \mathrm{M}$ progesterone at these glucose concentrations, the insulin degradation was restored to the same level as in the control islets. The effects of mifepristone were less clear at $28 \mathrm{mM}$ glucose.

\subsection{A-224817.0 decreases whereas WAY-161358 has no effect on intracellular degradation of insulin}

Involvement of steroid receptors in the effects of corticosterone and progesterone on the intracellular insulin degradation was further analysed by use of selective nonsteroidal receptor ligands (Fig. 5). At 3.3 or $5.5 \mathrm{mM}$ glucose, A-224817.0 at a concentration of $5 \mu \mathrm{M}$, in similarity to corticosterone, reduced the intracellular insulin degradation. On the contrary, 10 $\mu \mathrm{M}$ WAY-161358 did not affect the degradation at these concentrations of glucose. In incubations with $28 \mathrm{mM}$ glucose, none of the ligands caused any change in the degradation of insulin.

\subsection{Specific receptor effects decrease and increase islet production of prostaglandin $E_{2}$}

The islet production of prostaglandins was determined by measurements of $\mathrm{PGE}_{2}$ accumulation in the chase medium at a glucose concentration of $5.5 \mathrm{mM}$. In the presence of $20 \mu \mathrm{M}$ corticosterone the islet $\mathrm{PGE}_{2}$ production was decreased and with $20 \mu \mathrm{M}$ progesterone increased. Mifepristone at a concentration of $20 \mu \mathrm{M}$ did not change the production of $\mathrm{PGE}_{2}$. However, this substance abolished the effects of corticosterone and progesterone on the islet $\mathrm{PGE}_{2}$ production (Fig. 6).

The effect of corticosterone was mimicked with $5 \mu \mathrm{M}$ A-224817.0 that also reduced the $\mathrm{PGE}_{2}$ production. On the other hand, $10 \mu \mathrm{M}$ WAY-161358 had no effect on the islet production of the prostaglandin (Fig. 7).

\subsection{Inhibition of cyclooxygenase blocks intracellular degradation of insulin}

To estimate the role of prostaglandins for the intracellular degradation of insulin, the effects of indomethacin were determined (Fig. 8). The intracellular degradation of insulin that occurred in the islets at 3.3 and $5.5 \mathrm{mM}$ glucose was abolished, when $100 \mu \mathrm{M}$ indomethacin was added to the chase medium. At $28 \mathrm{mM}$ glucose, where there was no intracellular insulin degradation, indomethacin did not have any further effect. 


\section{Discussion}

This study showed a substantial intracellular degradation of radioactively labelled insulin in the pancreatic islets at low or physiologic glucose concentrations, whereas there was no degradation at a high glucose concentration. These results are in agreement with previous observations (Halban and Wollheim, 1980). Corticosterone inhibited and progesterone stimulated the intracellular degradation of insulin in the islets. The effects were detected at a steroid concentration of $1 \mu \mathrm{M}$, which is five to ten times higher than the normal plasma concentration in mice (Halberg et al., 1959; Solem, 1966; Michael, 1976; Bailey, 1987). However, in the present experiments the isolated islets had lost their microcirculation, and it is plausible that they had a low tissue extraction of the steroids.

Corticosterone and progesterone had divergent actions on the lysosomal population of the pancreatic $\beta$-cells. The lysosomes, which were identified by their content of acid phosphatase, appeared in the $\beta$-cells exposed to corticosterone mostly as dense bodies not involved in any degradative process. However, in the islets treated with progesterone the lysosomal population of the $\beta$-cells was predominated by large multigranular bodies. Hence, both the effects of the various glucose concentrations and of corticosterone and progesterone indicate an apparent concordance between intracellular degradation of insulin and crinophagy in the pancreatic $\beta$-cells.

Conceivably, the actions of the steroids on the intracellular degradation of insulin and crinophagy in the islet $\beta$-cells could be attributed to physicochemical effects on the lysosomal and secretory granule membranes. Some studies on artificial membrane models have shown opposite actions of this kind by glucocorticoids and progesterone (Roux and Baret, 1968; Heap et al., 1970), whereas other studies have not revealed any differing effects of glucocorticoids and progesterone (Kellaway and Saunders, 1967) and in particular not of corticosterone and progesterone (Bangham et al., 1965). As an alternative, it may be considered that the steroid effects could be mediated by specific membrane receptors (Wehling, 1997; Lösel and Wehling, 2003; Norman et al., 2004). However, mifepristone, which is an antagonist to the classical cytoplasmic receptors for glucocorticoids and for progesterone (Baulieu, 1991; Agarwal, 1996; Cadepond et al., 1997), abolished the effect of the steroids on the intracellular degradation of insulin. Thus, it is suggested that the action of these receptors mediate the effects of corticosterone and progesterone on the intracellular insulin degradation and crinophagy in the pancreatic islets. Both the glucocorticoid receptor 
(Fischer et al., 1990; Matthes et al., 1994) and the progesterone receptor (Green et al., 1978; Doglioni et al., 1990) are present in the $\beta$-cells. However, it is known that progesterone may bind to the glucocorticoid receptor with an affinity similar to the natural glucocorticoids (Chader and Reif-Lehrer, 1972; Moguilewsky and Deraedt, 1981; Rupprecht et al., 1993). When the pancreatic islets were exposed to the selective nonsteroidal receptor ligands at concentrations equipotent to those of the steroids, WAY-161358, which is a strong progesterone receptor agonist virtually without any cross-reactivity with the glucocorticoid receptor (Zhang et al., 2003), had in contrast to progesterone no effect on the intracellular degradation of insulin. On the other hand, the effect of corticosterone was mimicked by A224817.0, which has a high affinity for the glucocorticoid receptor (Elmore et al., 2001). Taken together these findings may indicate that both corticosterone and progesterone could affect intracellular degradation of insulin solely via the glucocorticoid receptor.

In all the present experiments there was a close correlation between islet intracellular insulin degradation and islet production of $\mathrm{PGE}_{2}$. Both corticosterone and A-224817.0, with its high transrepressive activity (Elmore et al., 2001), inhibited the islet $\mathrm{PGE}_{2}$ production. In combination with the in silico prediction of the cyclooxygenase-2 gene as a target for the transcription factor NF- $\kappa \mathrm{B}$ in the pancreatic $\beta$-cells (Naamane et al., 2007), these observations suggest that glucocorticoids alter islet $\beta$-cell prostaglandin production via receptor-regulated NF- $\kappa \mathrm{B}$ activity, as earlier described in other cell types (Barnes, 1998; McKay and Cidlowski, 1999; De Bosscher et al., 2003). Since progesterone, but not the progesterone receptor agonist WAY-161358, enhanced the islet production of $\mathrm{PGE}_{2}$, it is tempting to speculate that progesterone in the pancreatic $\beta$-cells facilitates NF-kB activity via binding to the glucocorticoid receptor. It has been observed that progesterone bound to the glucocorticoid receptor may exert both transactivation and transrepression (Koubovec et al., 2005), and maybe the steroid changes the ratio between the two processes in the pancreatic $\beta$-cells.

In summary, corticosterone and progesterone may exert their effects on islet intracellular insulin degradation and crinophagy by their control of prostaglandin production. The finding that indomethacin, an inhibitor of prostaglandin synthesis (Ferreira et al., 1971; Vane, 1971), abolished the islet intracellular degradation of insulin supports this notion and, furthermore, suggests a regulatory role for prostaglandins in intracellular turnover of secretory material in pancreatic islet $\beta$-cells.

\section{Acknowledgements}


The skilful technical assistance of Kärstin Flink and the financial support from the Swedish Research Council (72X-109) are gratefully acknowledged.

\section{References}

Agarwal, M.K., 1996. The antiglucocorticoid action of mifepristone. Pharmacol. Ther. 70, 183-213.

Bailey, K.J., 1987. Diurnal progesterone rhythms in the female mouse. J. Endocrinol. 112, 1521.

Bangham, A.D., Standish, M.M., Weissmann, G., 1965. The action of steroids and streptolysin S on the permeability of phospholipid structures to cations. J. Mol. Biol. 13, 253-259.

Barnes, P.J., 1998. Anti-inflammatory actions of glucocorticoids: molecular mechanisms. Clin. Sci. 94, 557-572.

Baulieu, E.-E., 1991. The steroid hormone antagonist RU486. Mechanism at the cellular level and clinical applications. Endocrinol. Metab. Clin. North Am. 20, 873-891.

Cadepond, F., Ulmann, A., Baulieu, E.-E., 1997. RU486 (mifepristone): mechanisms of action and clinical uses. Annu. Rev. Med. 48, 129-156.

Chader, G.J., Reif-Lehrer, L., 1972. Hormonal effects on the neural retina: corticoid uptake, specific binding and structural requirements for the induction of glutamine synthetase. Biochim. Biophys. Acta 264, 186-196.

De Bosscher, K., Vanden Berghe, W., Haegeman, G., 2003. The interplay between the glucocorticoid receptor and nuclear factor- $\mathrm{\kappa B}$ or activator protein-1: molecular mechanisms for gene repression. Endocr. Rev. 24, 488-522.

de Duve, C., 1969. The lysosome in retrospect. In: Dingle, J.T., Fell, H.B. (Eds.), Lysosomes in Biology and Pathology, Vol. 1. North-Holland Publishing Co., Amsterdam-London, pp. 3-40.

Doglioni, C., Gambacorta, M., Zamboni, G., Coggi, G., Viale, G., 1990. Immunocytochemical localization of progesterone receptors in endocrine cells of the human pancreas. Am. J. Pathol. 137, 999-1005.

Elmore, S.W., Coghlan, M.J., Anderson, D.D., Pratt, J.K., Green, B.E., Wang, A.X., Stashko, M.A., Lin, C.W., Tyree, C.M., Miner, J.N., Jacobson, P.B., Wilcox, D.M., Lane, B.C., 2001. Nonsteroidal selective glucocorticoid modulators: the effect of C-5 alkyl substitution on the transcriptional activation/repression profile of 2,5-dihydro-10- 
methoxy-2,2,4-trimethyl-1H-[1]benzopyrano[3,4-f]quinolines. J. Med. Chem. 44, 44814491.

Ferreira, S.H., Moncada, S., Vane, J.R., 1971. Indomethacin and aspirin abolish prostaglandin release from the spleen. Nat. New Biol. 231, 237-239.

Fischer B., Rausch, U., Wollny, P., Westphal, H., Seitz, J., Aumüller, G., 1990.

Immunohistochemical localization of the glucocorticoid receptor in pancreatic $\beta$-cells of the rat. Endocrinology 126, 2635-2641.

Green, I.C., Howell, S.L., El Seifi, S., Perrin, D., 1978. Binding of ${ }^{3}$ H-progesterone by isolated rat islets of Langerhans. Diabetologia 15, 349-355.

Halban, P.A., Wollheim, C.B., 1980. Intracellular degradation of insulin stores by rat pancreatic islets in vitro. An alternative pathway for homeostasis of pancreatic insulin content. J. Biol. Chem. 255, 6003-6006.

Halberg, F., Peterson, R.E., Silber, R.H., 1959. Phase relations of 24-hour periodicities in blood corticosterone, mitoses in cortical adrenal parenchyma, and total body activity. Endocrinology 64, 222-230.

Heap, R.B., Symons, A.M., Watkins, J.C., 1970. Steroids and their interactions with phospholipids: solubility, distribution coefficient and effect on potassium permeability of liposomes. Biochim. Biophys. Acta 218, 482-495.

Heding, L.G., 1972. Determination of total serum insulin (IRI) in insulin-treated diabetic patients. Diabetologia 8, 260-266.

Kellaway, I.W., Saunders, L., 1967. The solubilization of some steroids by phosphatidyl choline and lysophosphatidyl choline. Biochim. Biophys. Acta 144, 145-148.

Koubovec, D., Ronacher, K., Stubsrud, E., Louw, A., Hapgood, J.P., 2005. Synthetic progestrins used in HRT have different glucocorticoid agonist properties. Mol. Cell. Endocrinol. 242, 23-32.

Lösel, R., Wehling, M., 2003. Nongenomic actions of steroid hormones. Nat. Rev. Mol. Cell Biol. 4, 46-56.

Matthes, H., Kaiser, A., Stier, U., Riecken, E.-O., Rosewicz, S., 1994. Glucocorticoid receptor gene expression in the exocrine and endocrine rat pancreas. Endocrinology $135,476-479$.

McKay, L.I., Cidlowski, J.A., 1999. Molecular control of immune/inflammatory responses: interactions between nuclear factor- $\kappa \mathrm{B}$ and steroid receptor-signaling pathways. Endocr. Rev. 20, 435-459.

Michael, S.D., 1976. Plasma prolactin and progesterone during the estrous cycle in the mouse. Proc. Soc. Exp. Biol. Med. 153, 254-257. 
Miller, W.S., Smith, Jr., J.G., 1966. Effect of acetylsalicylic acid on lysosomes. Proc. Soc. Exp. Biol. Med. 122, 634-636.

Moguilewsky, M., Deraedt, R., 1981. Interrelations between glucocorticoid and progestin receptors. J. Steroid Biochem. 15, 329-335.

Naamane, N., van Helden, J., Eizirik, D.L., 2007. In silico identification of NF-kappaBregulated genes in pancreatic beta-cells. BMC Bioinformatics 8, 55.

Norman, A.W., Mizwicki, M.T., Norman, D.P.G., 2004. Steroid-hormone rapid actions, membrane receptors and a conformational ensemble model. Nat. Rev. Drug Discov. 3, $27-41$.

Roux, R., Baret, J.-F., 1968. Vérification expérimentale de la loi de Szyszkowski pour l'adsorption de certains stéroïdes a l'interface huile-eau. J. Chim. Phys. 65, 2163-2165.

Rupprecht, R., Reul, J.M.H.M., van Steensel, B., Spengler, D., Söder, M., Berning, B., Holsboer, F., Damm, K., 1993. Pharmacological and functional characterization of human mineralocorticoid and glucocorticoid receptor ligands. Eur. J. Pharmacol. Mol. Pharmacol. Sect. 247, 145-154.

Schnell, A.H., Borg L.A.H., 1985. Lysosomes and pancreatic islet function. Glucosedependent alterations of lysosomal morphology. Cell Tissue Res. 239, 537-545.

Schnell, A.H., Swenne, I., Borg, L.A.H., 1988. Lysosomes and pancreatic islet function. A quantitative estimation of crinophagy in the mouse pancreatic B-cell. Cell Tissue Res. 252, 9-15.

Schnell Landström, A.H., Andersson, A., Borg, L.A.H., 1991. Lysosomes and pancreatic islet function: adaptation of $\beta$-cell lysosomes to various metabolic demands. Metab. Clin. Exp. 40, 399-405.

Smith, R.E., Farquhar, M.G., 1966. Lysosome function in the regulation of the secretory process in cells of the anterior pituitary gland. J. Cell Biol. 31, 319-347.

Solem, J.H., 1966. Plasma corticosteroids in mice. With special regard to sex difference in adrenocortical responsiveness to exogenous corticotrophin. Scand. J. Clin. Lab. Invest. 18, Suppl. 93, 1-36.

Symons, A.M., Lewis, D.A., Ancill, R.J., 1969. Stabilising action of anti-inflammatory steroids on lysosomes. Biochem. Pharmacol. 18, 2581-2582.

Vane, J.R., 1971. Inhibition of prostaglandin synthesis as a mechanism of action for aspirinlike drugs. Nat. New Biol. 231, 232-235.

Wehling, M., 1997. Specific, nongenomic actions of steroid hormones. Annu. Rev. Physiol. $59,365-393$. 
Weissmann, G., 1965. Studies of lysosomes - VI. The effect of neutral steroids and bile acids on lysosomes in vitro. Biochem. Pharmacol. 14, 525-535.

Zhang, P., Terefenko, E.A., Fensome, A., Wrobel, J., Winneker, R., Zhang, Z., 2003. Novel 6-aryl-1,4-dihydrobenzo[ $d][1,3]$ oxazine-2-thiones as potent, selective, and orally active nonsteroidal progesterone receptor agonists. Bioorg. Med. Chem. Lett. 13, 1313-1316. 


\section{Figure legends}

Fig. 1. Effects of corticosterone or progesterone on intracellular degradation of insulin in pancreatic islets at 3.3 (A), 5.5 (B) or 28 (C) $\mathrm{mM}$ glucose. Results are given as mean values \pm S.E.M. for 8 - 10 observations. ${ }^{*} p<0.05,{ }^{* *} p<0.01,{ }^{* * *} p<0.001$ indicate probability of chance for no insulin degradation at each experimental condition. ${ }^{\dagger} p<0.05,{ }^{\dagger \dagger} p<0.01,{ }^{\dagger \dagger} p$ $<0.001$ versus control islets.

Fig. 2. Effects of glucose on pancreatic islet ultrastructure. (A) A $\beta$-cell at $3.3 \mathrm{mM}$ glucose showing a lysosome with heterogeneous inclusions partly resembling membrane fragments. (B) A $\beta$-cell at $5.5 \mathrm{mM}$ glucose with a multigranular body containing secretory granules. (C) A $\beta$-cell at $28 \mathrm{mM}$ glucose displaying a dense body with homogenous, very fine, particulate content and a narrow light rim just beneath the surrounding membrane. Magnification 33900 $\times$.

Fig. 3. Effects of corticosterone or progesterone on pancreatic islet ultrastructure. (A) A $\beta$-cell exposed to $100 \mu \mathrm{M}$ corticosterone at $3.3 \mathrm{mM}$ glucose showing a dense body. (B) A $\beta$-cell exposed to $100 \mu \mathrm{M}$ progesterone at $28 \mathrm{mM}$ glucose with a multigranular body. Magnification $33900 \times$. Insets show cytochemically reactive acid phosphatase completely filling a dense body (A) or displaying a patchy distribution within a multigranular body (B). Magnification $51000 \times$.

Fig. 4. Effects of corticosterone or progesterone and/or mifepristone on intracellular degradation of insulin in pancreatic islets at 3.3 (A), 5.5 (B) or 28 (C) $\mathrm{mM}$ glucose. Results are given as mean values \pm S.E.M. for 8 - 10 observations. ${ }^{*} p<0.05,{ }^{* *} p<0.01,{ }^{* * *} p<$ 0.001 indicate probability of chance for no insulin degradation at each experimental condition. ${ }^{\dagger} p<0.05,{ }^{\dagger \dagger} p<0.01,{ }^{\dagger \dagger \dagger} p<0.001$ versus control islets.

Fig. 5. Effects of A-224817.0 or WAY-161358 on intracellular degradation of insulin in pancreatic islets at 3.3 (A), 5.5 (B) or 28 (C) $\mathrm{mM}$ glucose. Results are given as mean values \pm S.E.M. for 8 - 10 observations. ${ }^{*} p<0.05,{ }^{* * *} p<0.001$ indicate probability of chance for no insulin degradation at each experimental condition. ${ }^{\dagger \dagger} p<0.001$ versus control islets. 
Fig. 6. Effects of corticosterone or progesterone and/or mifepristone on prostaglandin $\mathrm{E}_{2}$ production of pancreatic islets at $5.5 \mathrm{mM}$ glucose. Results are given as mean values \pm S.E.M. for 12 - 15 observations. ${ }^{\dagger \dagger} p<0.001$ versus control islets.

Fig. 7. Effects of A-224817.0 or WAY-161358 on prostaglandin $E_{2}$ production of pancreatic islets at $5.5 \mathrm{mM}$ glucose. Results are given as mean values \pm S.E.M. for 7 - 9 observations. ${ }^{\dagger \dagger}$ $p<0.01$ versus control islets.

Fig. 8. Effects of indomethacin on intracellular degradation of insulin in pancreatic islets at 3.3, 5.5 or $28 \mathrm{mM}$ glucose. Results are given as mean values \pm S.E.M. for 6 observations. $p<0.001$ indicate probability of chance for no insulin degradation at each experimental condition. ${ }^{\dagger \dagger} p<0.01,{ }^{\dagger \dagger} p<0.001$ versus control islets at each glucose concentration. 
Table 1 Effects of glucose on insulin in pancreatic islets

\begin{tabular}{lllll}
\hline $\begin{array}{l}\text { Glucose concentration } \\
(\mathrm{mM})\end{array}$ & $\begin{array}{l}\text { Islet insulin } \\
\text { content }(\%)\end{array}$ & $\begin{array}{l}\text { Medium insulin } \\
\text { content }(\%)\end{array}$ & $\begin{array}{l}\text { Total insulin } \\
(\%)\end{array}$ & $\begin{array}{l}\text { Degraded } \\
\text { insulin }(\%)\end{array}$ \\
\hline 3.3 & $60.6 \pm 2.4$ & $2.4 \pm 0.8$ & $62.3 \pm 2.4$ & $37.7 \pm 2.4$ \\
5.5 & $59.8 \pm 3.3$ & $3.8 \pm 0.7$ & $63.1 \pm 3.2$ & $36.9 \pm 3.2$ \\
28 & $24.8 \pm 1.1 * * *$ & $79.3 \pm 6.3 * * *$ & $106.6 \pm 6.4 * * *$ & $-6.6 \pm 6.4$ \\
\hline
\end{tabular}

Results are given as mean values \pm S.E.M. for 10 observations. $* * * P<0.001$ versus islets incubated at $5.5 \mathrm{mM}$ glucose. 
A

Control

1 pta Corticosterone

10 utu Corticosterone

100 put Corticosterane

1 pM Progesterone

10 pM Progeteteron

100 phu Progesterone

B

Control

1 yM Corticosterone

10 pa Corticosterone

100 pat Carticosterone

1 yM Progesterone

10 jus Progesterone

100 ut Progesterone

C

Control

1 aM Corticosterone

10 ju Corticosterone

100 pM Corticosterane

1 uM Progesteroene

10 jata Progesterone

100 pu Progestecono
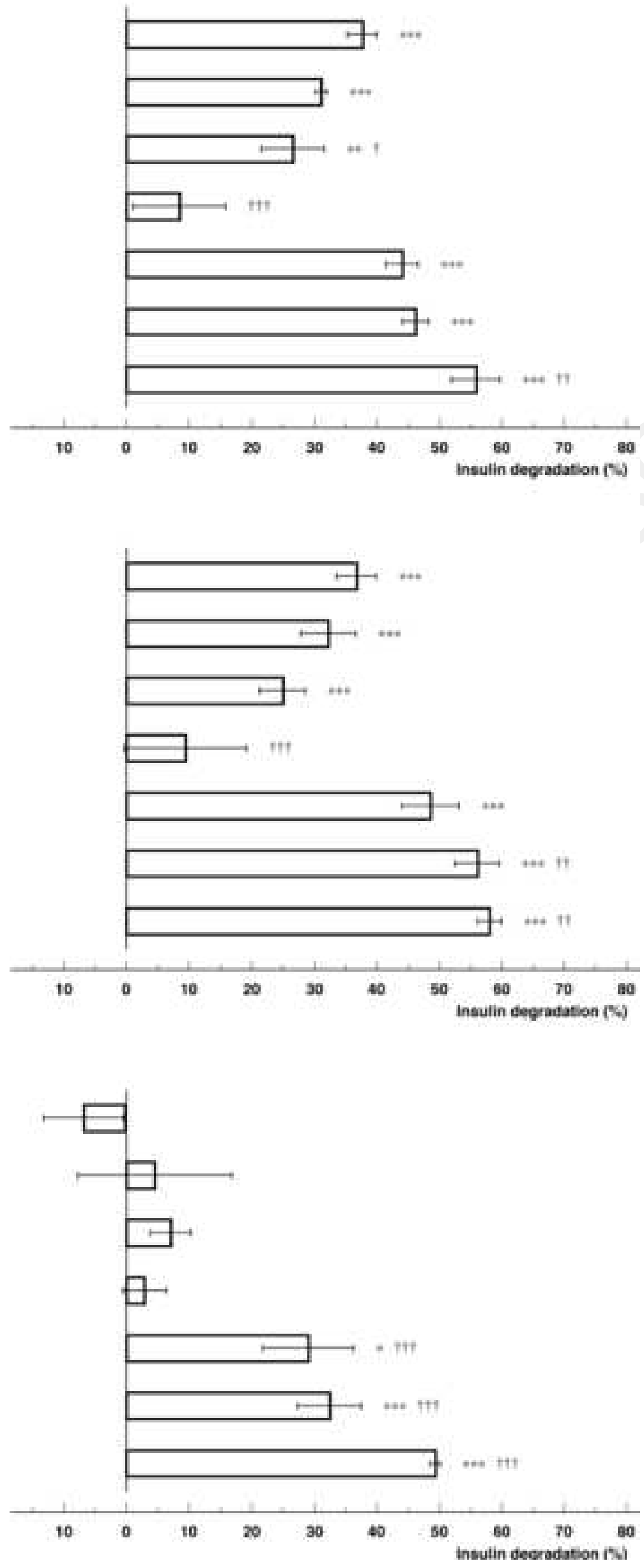

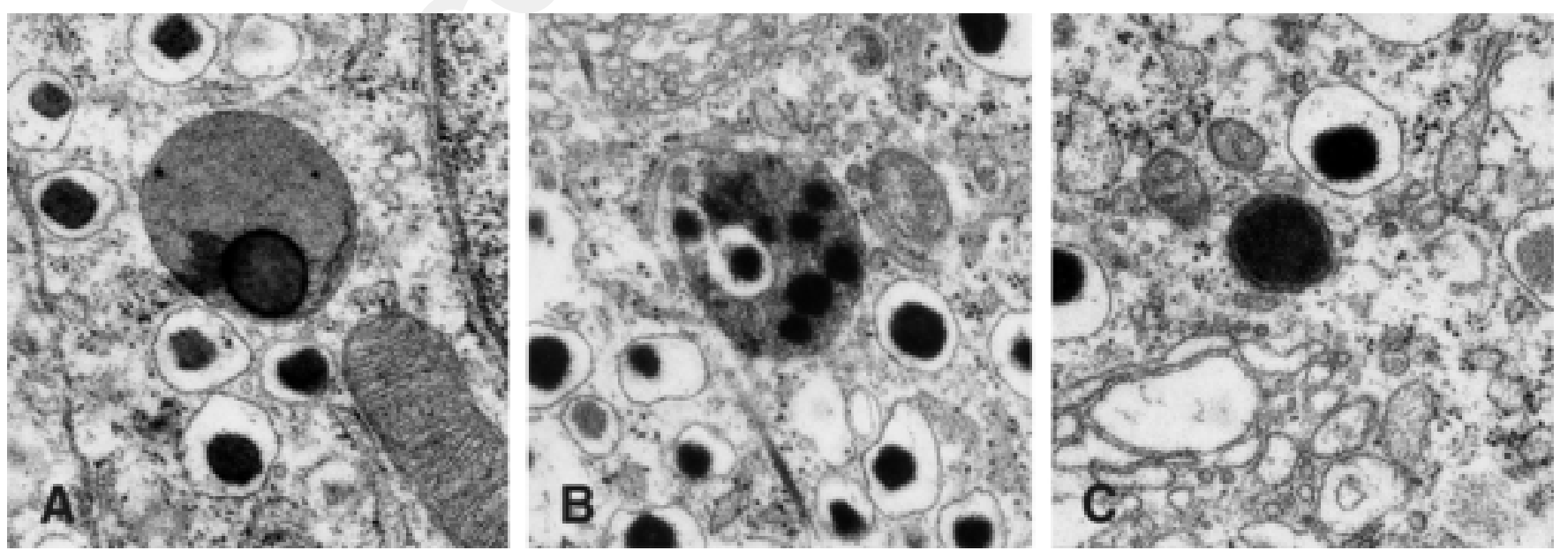

Page 19 of 25 

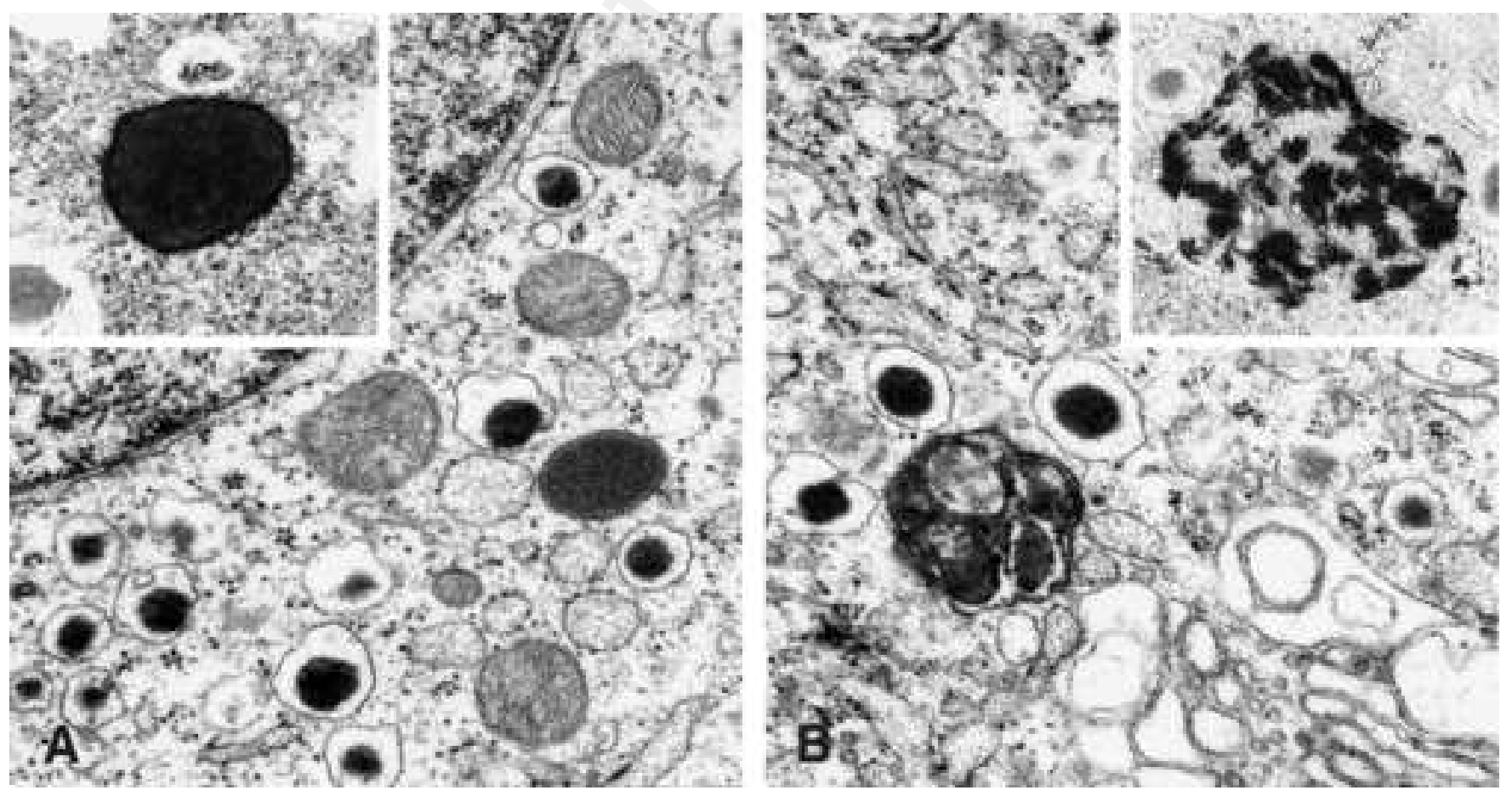
A

Control

20 jM Corticosterone

20 pM Progesterone

20 jM Mifepristone

20 jM Milepristone

$+20 \mu \mathrm{M}$ Corticonterone

20 jM Mifepristone

+20 pha Progesterone

B

Control

20 MM Corticosterone

20 jM Progesterone

20 pM Mifepristone

20 jM Mifeprintone $+20 \mu \mathrm{Am}$ Corticosterone

20 ja Mifepristone +20 M Progesterone

C

Control

20 pM Corticosterone

20 HM Progesterone

20 jM Mifepristone

20 iM Mifepristone +20 MM Corticosterone

20 jM Mifepristone +20 uM Progesterone
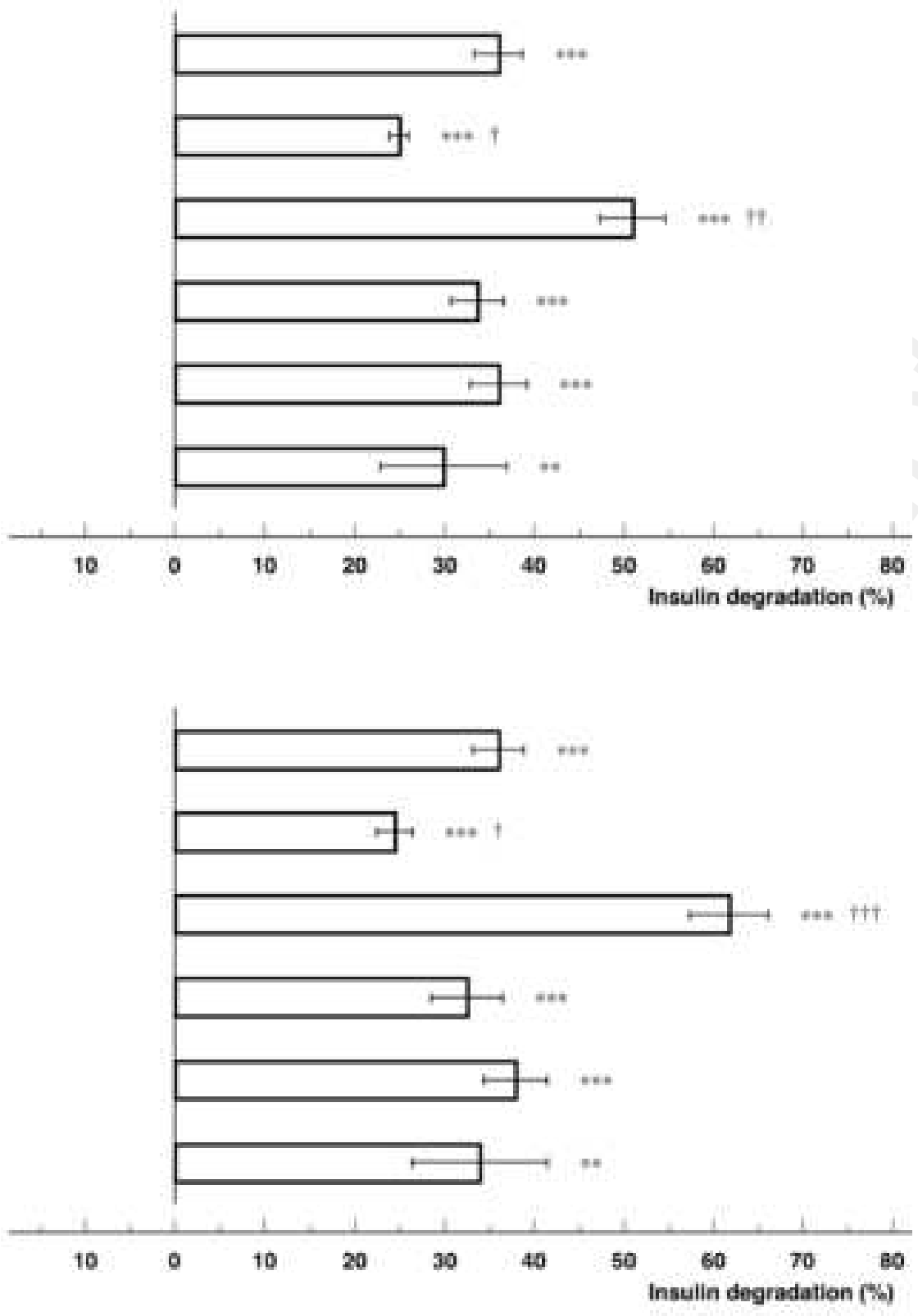
A

Control

$5 \mu \mathrm{M}$ A-224817.0

$10 \mu M$ WAY-161358

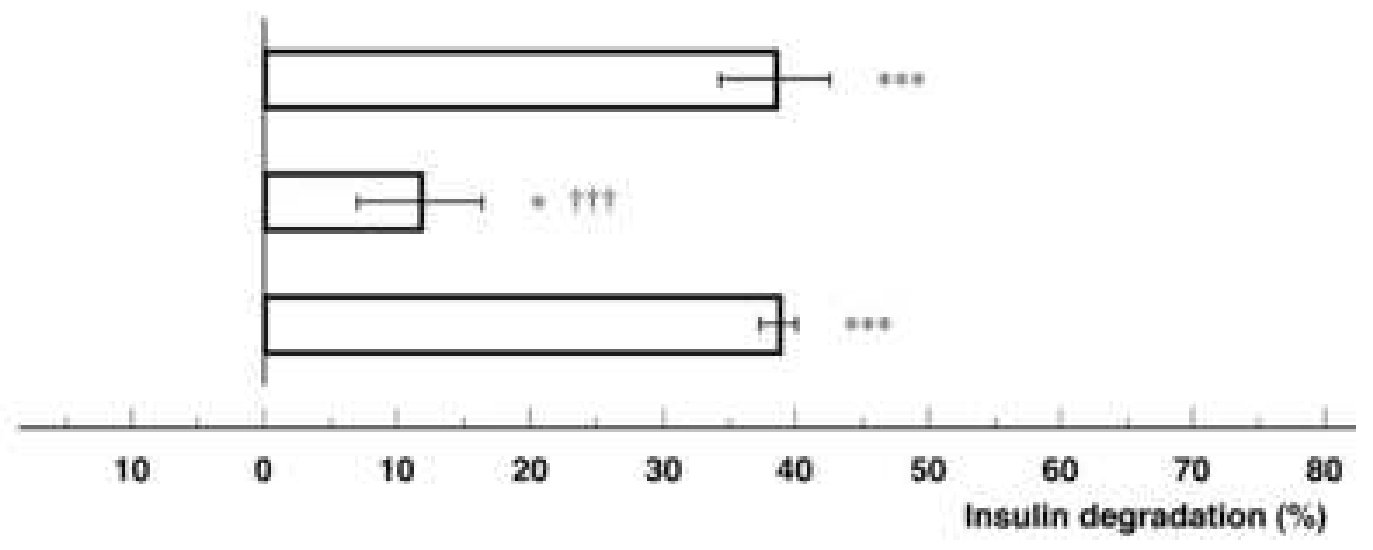

B

Control

$5 \mu \mathrm{M} \mathrm{A}-224817.0$

$10 \mu M$ WAY- 161358

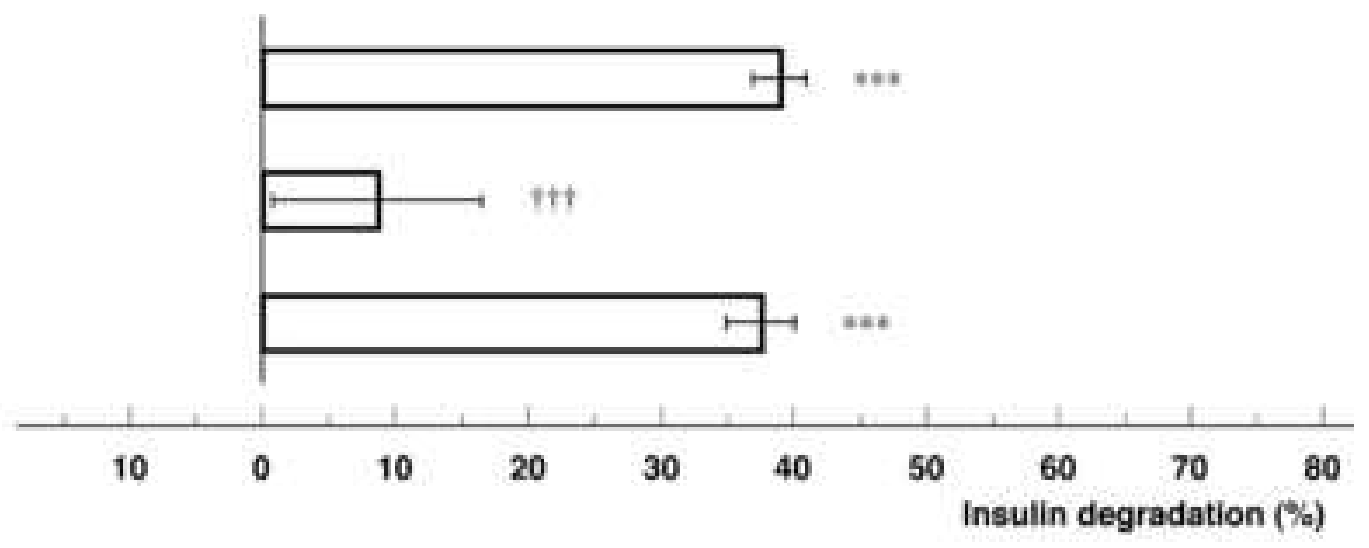

C

Control

$5 \mu \mathrm{M}$ A-224817.0

$10 \mu M$ WAY-161358

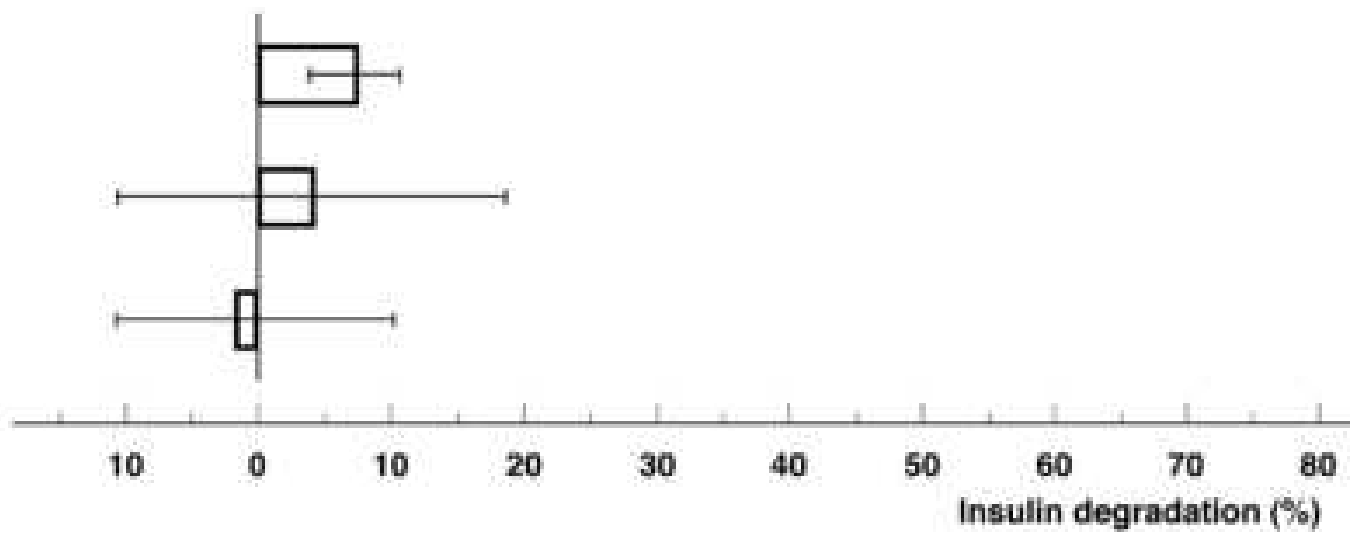

Page 22 of 25 


\section{Control}

$20 \mu \mathrm{M}$ Corticosterone

$20 \mu \mathrm{M}$ Progesterone

$20 \mu \mathrm{M}$ Mifepristone

$20 \mu \mathrm{M}$ Mifepristone $+20 \mu \mathrm{M}$ Corticosterone

$20 \mu \mathrm{M}$ Mifepristone $+20 \mu \mathrm{M}$ Progesterone

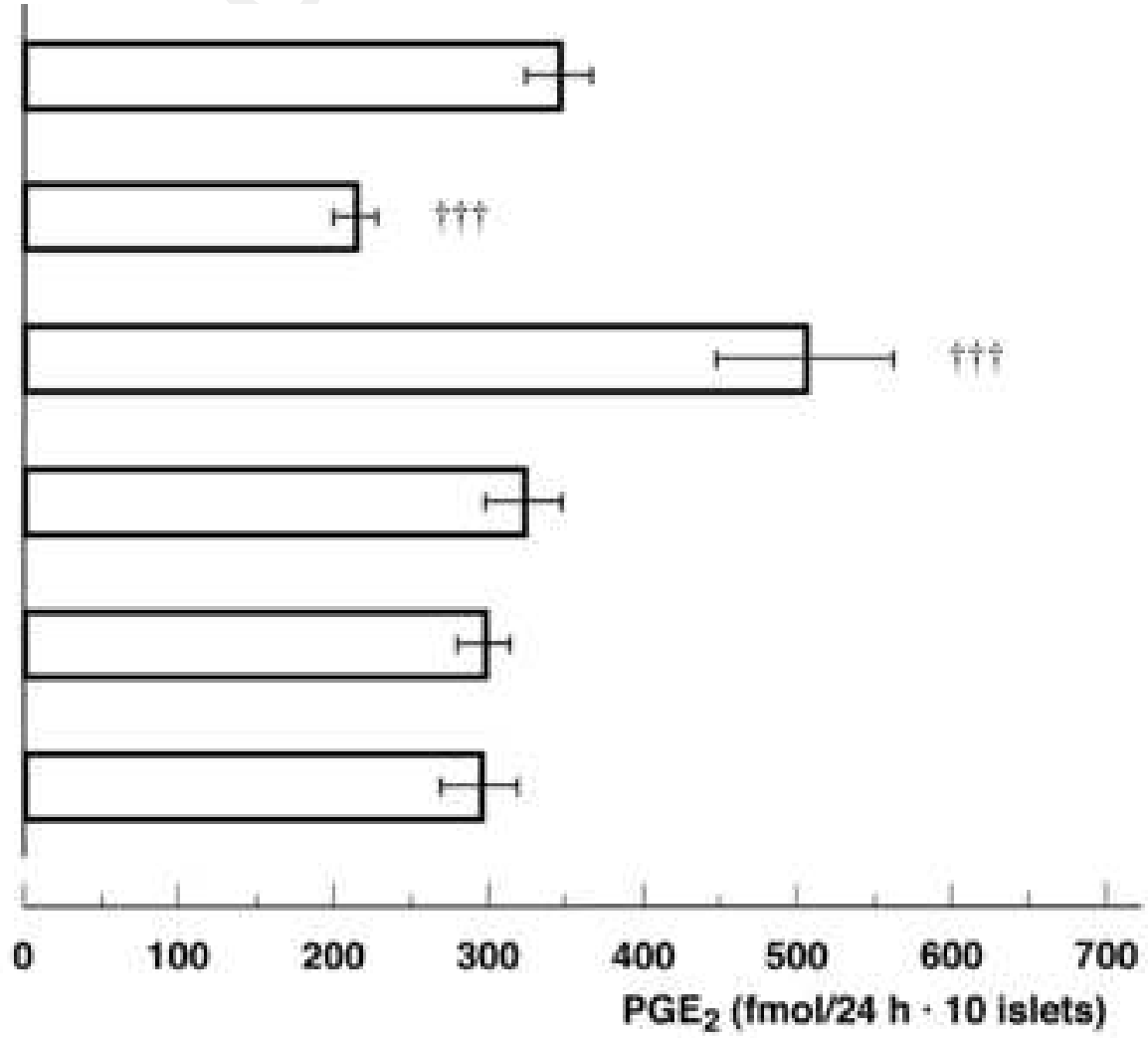




\section{Control}

$5 \mu \mathrm{M}$ A-224817.0

$10 \mu \mathrm{M}$ WAY-161358
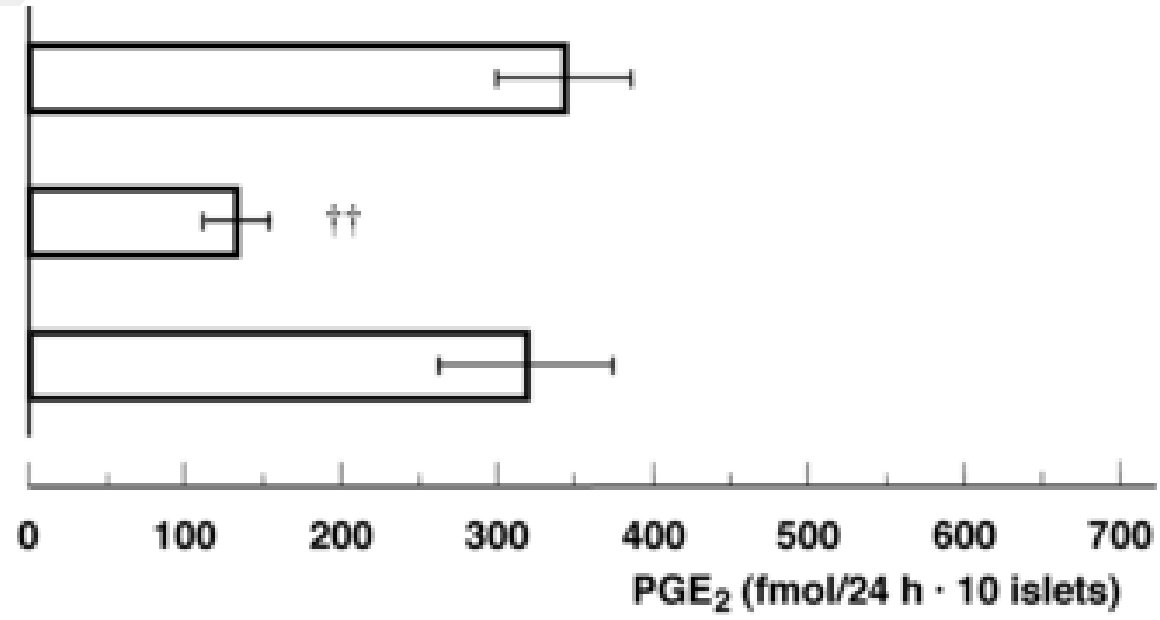


\section{$3.3 \mathrm{mM}$ Glucose}

$3.3 \mathrm{mM}$ Glucose

$+100 \mu \mathrm{M}$ Indomethacin

\section{$5.5 \mathrm{mM}$ Glucose}

$5.5 \mathrm{mM}$ Glucose

$+100 \mu \mathrm{M}$ Indomethacin

$28 \mathrm{mM}$ Glucose

$28 \mathrm{mM}$ Glucose $+100 \mu \mathrm{M}$ Indomethacin

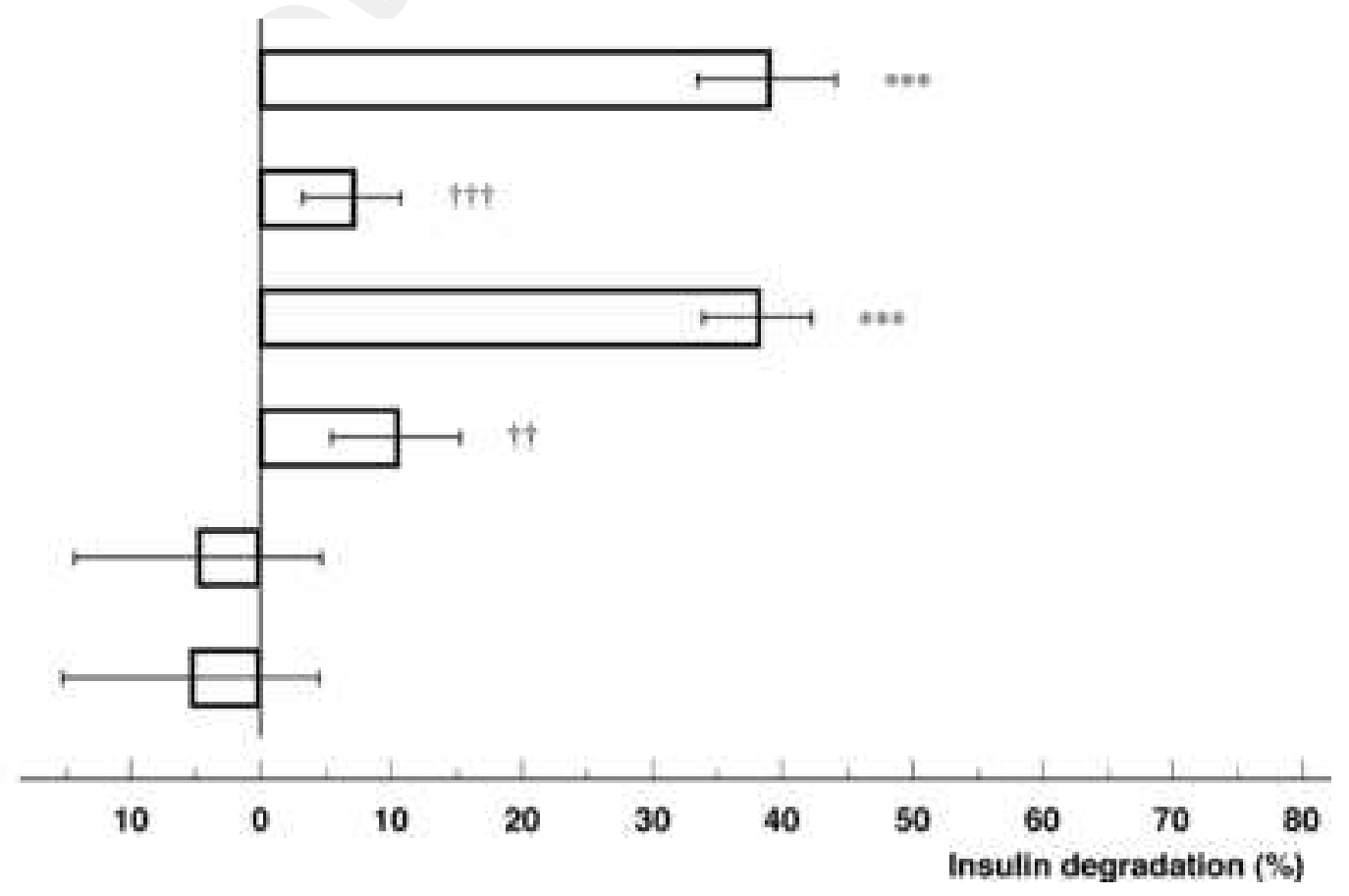

